\title{
INTERNALISASI NILAI-NILAI MORAL AGAMA PADA ANAK USIA DINI
}

\author{
SAPENDI \\ Dosen Jurusan PGRA IAIN Pontianak dan Kepala LPM IAIN Pontianak
}

\begin{abstract}
ABSTRAK
As the next generation of the family and the nation, children need to obtain good education so that their personal potential can develop, and they will grow to be strong and have a wide range of useful abilities and skills. It is therefore important for the family and educational institutions to take part in and be responsible for providing a wide variety of stimulation and guidance that will create a tough future generation. Childhood, especially at an early age or between 0 to 8 years, is often called the golden years, because in this stage, various abilities of children grow rapidly. Giving appropriate stimulation and facilities in this phase will greatly affect the subsequent process of their development. In contrast, when the environment around them such as parents, educators, and society fail to provide appropriate stimulation to their abilities, they will not grow as expected. Internalization of moral and religious values help to increase and guide the development of children. Establishment of moral and religious values in children is not merely a routine worship activities, but rather it should be instilled in a direct, concrete way and appropriate to a child's language in the conduct of daily life. Introducing moral and religious values since early childhood will hopefully be a guide for him in the future.
\end{abstract}

Keywords: internalization of moral values, religious values, early childhood

\section{PENDAHULUAN}

Setiap anak yang dilahirkan di muka bumi ini memerlukan pendidikan. Pendidikan yang dilakukan harus diawasi dan dipelihara secara terus menerus sebagai bentuk pelatihan dasar dalam membentuk sikap dan kebiasaan agar anak memiliki kemungkinan untuk berkembang secara wajar dan optimal dalam setiap tahap perkembangannya dalam kehidupan di masa datang. Untuk membentuk sikap, perilaku dan kebiasaan anak yang baik, agama memiliki peran yang sangat besar (Jalaluddin Rahmat, 204:1995). Dengan agama maka pertumbuhan dan perkembangan anak akan berjalan dengan baik. Islam sebagai agama yang universal mengatur seluruh aspek kehidupan manusia, mulai dari ibadah, kehidupan sosial, dan mengatur bagaimana membentuk dan kepribadian dan perilaku anak agar memiliki akhlak yang baik.

Pendidikan Islam merupakan pendidikan universal yang diperuntukkan untuk seluruh umat manusia. Pendidikan Islam memiliki nilai-nilai luhur yang agung dan mampu menentukan posisi dan fungsi di dalam masyarakat Indonesia. Selain itu, Pendidikan Islam merupakan sistem pendidikan yang diperuntukkan untuk melatih anak didik agar memiliki nilai dan kepribadian yang sesuai dengan tuntunan moral dan agama. Pendidikan Islam dibentuk sedemikian rupa sehingga dalam sikap hidup, tindakan, 
dan pendekatannya dalam segala jenis pengetahuan banyak dipengaruhi oleh nilai- nilai spiritual dan sangat sadar akan nilai etika Islam (Abdurrahman, 1992:187).

Agama sangat berperan dalam pembentukan perilaku anak, sehingga pembentukan pribadi anak akan membaur sesuai pertumbuhan dan perkembangan anak. Sehingga diperlukan pendidikan dengan persyaratanpersyaratan tertentu dan pengawasan serta pemeliharaan yang terus-menerus. Kemudian pelatihan dasar dalam pembentukan kebiasaan dan sikap memiliki kemungkinan untuk berkembang secara wajar dalam kehidupan di masa mendatang (Jalaluddin Rahmat, 204:1995).

Menurut Wahyudi (2005:28) Penerapan pendidikan nilai Islam pada pendidikan usia dini harus melibatkan seluruh elemen yang menunjang iklim sekolah,agar terjadi interaksi positif antara anak didik dengan nilai-nilai yang akan diinternalisasi atau ditanamkan. Guru sebagai suri teladan (role model) dalam kegiatan belajar mengajar harus berkomunikasi dua arah dengan anak berdasarkan keikhlasannya.

Untuk membina agar anak mempunyai sifat terpuji, tidaklah mungkin dengan penjelasan pengertian saja, akan tetapi perlu membiasakannya untuk melakukan yang terbaik dan diharapkan nantinya akan mempunyai sifat-sifat terpuji dan bisa menjauhi sifat yang tercela. Latihan-latihan beragama yang menyangkut seperti ibadah salat berjama ${ }^{e e} a h$, puasa, zakat, doa-doa dan menghafal surat pendek harus dibiasakan sejak kecil agar nantinya bisa merasakan manisnya beribadah. Pada dasarnya apabila sejak dini anak dasar iman kepada Allah SWT, takut kepada-Nya, meminta tolong dan berserah diri kepada-Nya, niscaya ia akan mempunyai kemampuan fitri dan tanggapan naluri untuk menerima setiap keutamaan dan kemuliaan, dan akan terbiasa dengan akhlaq mulia (Ulwan, 1990: 169)

Dalam Islam, eksistensi anak melahirkan adanya dua hubungan yaitu vertikal dengan Allah SWT sebagai penciptanya, dan hubungan horizontal dengan orang tua dan masyarakat yang bertanggung jawab untuk mendidiknya agar menjadi manusia yang taat beragama. Walaupun fitrah kejadian anak itu suci, akan tetapi pada diri anak itu mempunyai dwi potensi, yaitu bisa menjadi baik jika melalui pendidikan yang benar dan bisa jadi buruk karena asuhan yang salah, tidak berpendidikan dan tanpa norma- norma agama Islam (Barmawi, 1993:5).

Masa anak-anak yang ada pada rentang usia 3-6 tahun disebut juga masa pra sekolah yang merupakan masa bahagia bagi anak (Patmonodewo, 2000: 19). Masa pra sekolah adalah masa pertumbuhan, masa ini merupakan masa yang tepat untuk meletakkan dasar-dasar pengembangan kemampuan fisik, bahasa, sosial, emosional dan nilainilai agama, sehingga usaha pengembangan seluruh potensi anak usia dini harus dimulai agar pertumbuhan dan perkembangan anak tercapai.

Pada masa ini juga merupakan masa ekspresi kreatifitas seperti bermain, suka cerita, mencoret-coret dinding, lari-lari dan sebagainya. Untuk itu sebagai orang tua ataupun pendidik perlu menjaga hal tersebut berjalan seperti mestinya. Janganlah memaksa kehendaknya hanya untuk kepentingan pihak sendiri dan jangan mencoba untuk melakukan hal-hal yang belum siap bagi anak karena akan mengakibatkan kreatifitas anak akan menjadi beku.

Pendidikan sendiri tidak dapat dipisahkan dari kehidupan manusia baik dalam keluarga, masyarakat maupun dalam kehidupan berbangsa dan bernegara. Pendi- 
dikan merupakan tanggungjawab bersama antara keluarga, masyarakat, dan pemerintah (Zakiah Darajat, 1996: 34).

Sebagai pendidik, baik orang tua maupun pendidik di sekolah bertanggungjawab terhadap kesejahteraan jiwa anak. Kedua pendidik tersebut mempunyai wewenang mengarahkan perilaku anak sebagaimana yang diinginkan, jika orang tua bertanggungjawab terhadap kesejahteraan fisik dan perkembangan keagamaan anak selama di rumah. Sedangkan pendidik di sekolah juga ikut bertanggungjawab untuk merangsang dan membina perkembangan sikap dan keagamaan anak. Orang tua dan pendidik saling melengkapi dalam pembinaan anak dan diharapkan ada saling pengertian dan kerja sama yang erat antara keduanya dalam usaha mencapai tujuan bersama yaitu kesejahteraan jiwa agama anak.

\section{MORAL KEAGAMAAN ANAK}

\section{a. Pengertian Moral Keagamaan}

Istilah moral kadang-kadang dipergunakan sebagai kata yang sama dengan etika. Moral berasal dari bahasa latin " $m o s "$ (adat istiadat, kebiasaan, cara tingkah laku, kelakuan), "mores" (adat istiadat, tabiat, kelakuan, watak, akhlak, cara hidup). Secara etimologi moral dan etika mempunyai arti yang sama karena keduanya berasal dari kata yang mengandung arti adat kebiasaan. Sedangkan etika berasal dari bahasa Yunani, "ethos" (jamak: ta etha). Moral diartikan sebagai nilai dan norma yang menjadi pegangan bagi seseorang dalam mengatur tingkah lakunya. Sebagaimana pendapat Helden dan Richards yang dikutip oleh Sjarkawi, moral diartikan sebagai suatu kepekaan dalam pikiran, perasaan dan tindakan dibandingkan dengan tindakan lain yang tidak hanya berupa kepekaan terhadap prinsip dan atur- an. Selanjutnya Atkinson (dalam Sjarkawi, 2000:28) berpendapat bahwa, moral merupakan pandangan tentang baik dan buruk, benar dan salah, apa yang dapat dan tidak dapat dilakukan. Selain itu juga moral merupakan seperangkat keyakinan dalam suatu masyarakat berkenaan dengan karakter atau kelakuan dan apa yang seharusnya dilakukan oleh manusia (Sjarkawi, 2006:28).

Sedangkan yang dimaksud disini adalah moral keagamaan yang berarti nilai atau norma yang dijadikan pegangan bagi seseorang atau kelompok masyarakat yang mengatur tingkah laku dalam kehidupan yang didasarkan pada keyakinan atau agama yang dianut baik itu hubungannya dengan Allah maupun dengan sesama manusia moral dalam tulisan.

\section{b. Nilai-Nilai Moral Keagamaan yang Harus di Internalisasi pada Anak}

Nilai-nilai menurut Pandangan Islam yang harus ditanamkan pada pendidikan anak usia dini adalah:

\section{1) Nilai Keimanan}

Iman menurut Rois Mahfud (2011: 12-13) secara umum dapat dipahami sebagai suatu keyakinan yang dibenarkan di dalam hati, diikrarkan dengan lisan, dan dibuktikan dengan amal perbuatan yang didasari niat yang tulus dan ikhlas dan selalu mengikuti petunjuk Allah SWT serta sunah Nabi Muhammad SAW.

Dalam Al-Quran terdapat sejumlah ayat yang menunjukkan kata-kata iman, diantaranya terdapat pada firman Allah surat al-Anfal ayat 2:

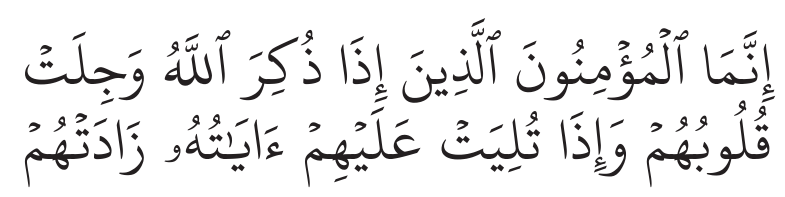




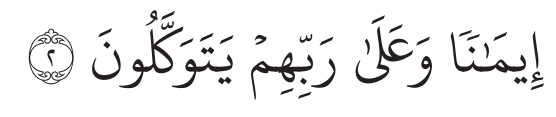

Sesungguhnya orang-orang yang beriman ialah mereka yang bila disebut nama Allah gemetarlah hati mereka, dan apabila dibacakan ayatayat-Nya bertambahlah iman mereka (karenanya), dan hanya kepada Tuhanlah mereka bertawakkal

Najib Khalid Al-Amir (2002:145) menjelaskan bahwa, pembinaan keimanan merupakan pembinaan yang pertama kali harus ditanamkan dalam jiwa dan pikiran anak sehingga pengembangan fitrah bagi manusia yang mempunyai sifat dan kecenderungan untuk mengakui dan mempercayai adanya Tuhan.

Sehingga dapat disimpulkan bahwa, nilai keimanan merupakan nilai pertama yang ditanamkan anak usia dini, karena pada usia tersebut anak cenderung bersifat imitatif. Mereka juga masih berimajinasi dalam berfikir. Kebanyakan dari mereka masih menyerupakan Tuhan dengan berfikir jika Tuhan itu maha melihat dan mendengar berarti mata besar dan telinga besar.

Peran orang tua sangat berpengaruh bagi tingkat keimanan anak melalui bimbingan orang tua anak dapat dibimbing untuk mengenal siapa itu Tuhan, sifat-sifat Tuhan, bagaimana kewajiban manusia terhadap Tuhan. Dalam Al-Quran juga dijelaskan dalam surat Luqman ayat 13:

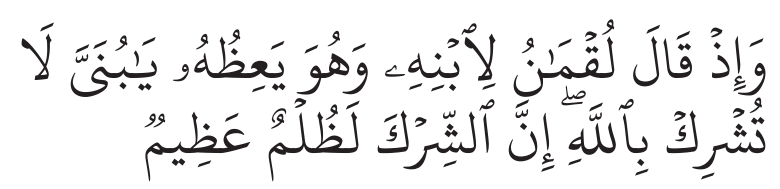

Dan (ingatlah) ketika Luqman berkata kepada anaknya, di waktu ia memberi pelajaran kepadanya: "Hai anakku, janganlah kamu mempersekutukan
Allah, sesungguhnya mempersekutukan (Allah) adalah benar-benar kezaliman yang besar"

Dari penjelasan ayat di atas dijelaskan bahwa, Allah mengingatkan kepada Rasulullah nasihat yang pernah diberikan Luqman kepada putranya ketika ia memberi pelajaran kepadanya. Nasihat itu adalah "Wahai anakku, Janganlah engkau mempersekutukan Allah, sesungguhnya mempersekutukan Dia (Allah) adalah kedzaliman yang besar.”

\section{2) Nilai Ibadah}

Ibadah dalam Islam secara garis besar terbagi kedalam dua jenis, yaitu ibadah mahdah (ibadah khusus) dan ibadah ghoiru mahdah (ibadah umum). Ibadah mahdah meliputi sholat, puasa, zakat dan haji. Sedangkan ibadah ghoiru mahdah meliputi shodaqoh, membaca Al-Qur'an dan lain sebagainya (Rois Mahfud, 2011:23). Penanaman nilai ibadah pada anak di mulai dari dalam keluarga. Karena anak masih kecil lebih menyukai kegiatan-kegiatan ibadah yang nyata seperti melaksanakan sholat. Sebagaimana hadist Nabi Muhammad SAW. yang diriwayatkan oleh Abu Dawud:

Dari Abdul Malik bin Rabi' bin Sabrah dari ayah nya dari kakeknya, yaitu Sabrah bin Ma'bad Al Juhni R.A. Dia berkata: Nabi SAW. Bersabda: "Suruhlah anak-anak mengerjakan shalat, apabila telah berumur tujuh tahun, dan pukullah dia karena meninggalkannya apabila telah berumur sepuluh tahun". Hadis ini juga dikeluarkan oleh Tirmidzi dan dinilai: Hadits Hasan Shahih. (H.R. Abu Dawud )

Menurut Norma Tarazi (2003) dalam bukunya The Children Islam: A Muslim Parent's Handbook, orang tua harus mengingatkan anak untuk melakukan shalat secara terus 
menerus ketika mereka sudah berusia tujuh tahun bahkan sepuluh tahun dengan lembut namun tegas.

Jadi, kewajiban melaksanakan sholat itu harus diajarkan sejak dini, lebih baik lagi bila diajarkan pada anak usia dini mereka mulai diajarkan bacaan sholat dan gerakan sholat meskipun mereka belum berusia tujuh tahun tetapi pengenalan tentang ibadah sholat itu juga sangat penting. Penanaman ibadah shalat ini dapat dilakukan pada pendidikan anak usia dini melalui kegiatan sebagai berikut (Wahyudi, 2005:42):

a) Guru membimbing anak untuk mempersiapkan sholat.

b) Guru memperkenalkan wudlu, pakaian bersih dan suci, mushola dan sebagainya.

c) Guru menjelaskan batasan-batasan aurat bagi laki-laki dan perempuan dalam sholat.

d) Anak mempraktekkan shalat berjamaah dalam kelompok kecil dan belajar untuk mengikuti imam.

e) Anak dilatih untuk tenang dan menjawab ketika mendengarkan adzan.

f) Anak dilatih untuk menghafalkan surat al-Fatihah.

g) Membiasakan anak untuk melaksanakan shalat tepat pada waktunya.

\section{3) Nilai Akhlak}

Akhlak menurut Nasiruddin (2010: 31) adalah kata jamak dari kata khuluq. Kata khuluq adalah lawan dari kata khalq. Khuluq merupakan bentuk batin sedangkan khalq merupakan bentuk lahir. Akhlak adalah sesuatu yang telah tercipta atau terbentuk melalui sebuah proses. Karena sudah terbentuk akhlak disebut juga dengan kebiasaan. Dalam pengertian sehari-hari akhlak umumnya disamakan artinya dengan budi pekerti, kesusilaan, sopan-santun. Tidak berbeda dengan arti kata moral, ethic dalam bahasa Inggris.
Menurut Mansur (2005:221) dalam bahasa Yunani, untuk pengertian akhlak ini dipakai kata ethos, ethiko yang kemudian menjadi etika. Manusia akan menjadi sempurna jika mempunyai akhlak terpuji (al-akhlaq al-muhammad) serta menjauhkan segala akhlak tercela (al-akhlaq al-mazmumah).

Akhlak bersumber pada Al-Qur'an, wahyu Allah yang tidak diragukan kebenarannya, dengan Nabi Muhammad SAW sebagai figur dari akhlak Al-Qur an suri tauladan. Sebagaimana terdapat dalam surat AlAhzab ayat 21:

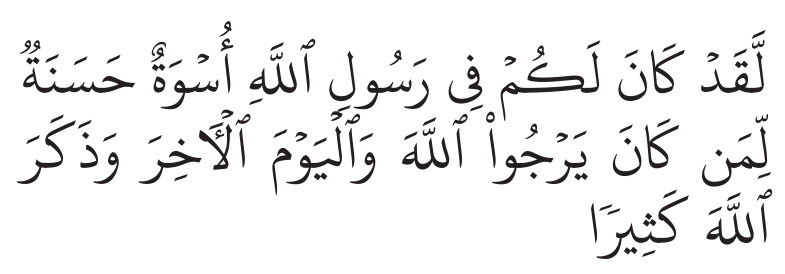

Sesungguhnya telah ada pada (diri) Rasulullah itu suri teladan yang baik bagimu (yaitu) bagi orang yang mengharap (rahmat) Allah dan (kedatangan) hari kiamat dan dia banyak menyebut Allah

Nilai Akhlak menurut Norma Tarazi (2003:165) dalam bukunya The Children/ Child in Islam: A Moeslem Parent"s Handbook, apabila anak dibesarkan dengan bimbingan akhlak yang mulia dari orang tua dan lingkungan yang kondusif maka ia akan memiliki banyak figur untuk diteladani dan membantu dalam pembentukan pribadi yang Islami pada diri anak. Karena akhlak pada anak terbentuk dengan meniru, bukan nasehat atau petunjuk. Anak selalu mengikuti tingkah laku orang tuanya. Maka diharapkan orang tua sebagai pendidik utama untuk lebih berhati-hati dalam bertindak dan memberikan yang baik. Di samping itu juga anak harus menghormati dan berbuat baik kepada kedua orang tua. Sebagaimana yang telah di- 
firmankan Allah SWT dalam al-Qur'an surat Luqman ayat 14 sebagai berikut:

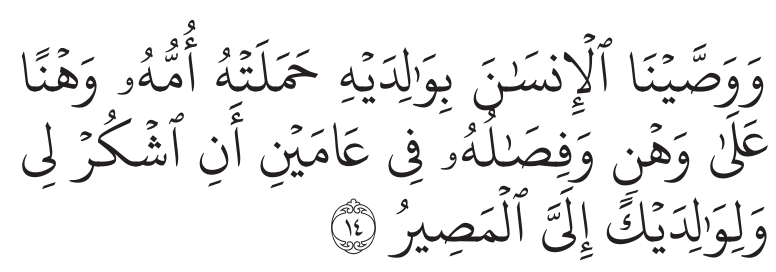

Dan Kami perintahkan kepada manusia (berbuat baik) kepada dua orang ibu-bapaknya; ibunya telah mengandungnya dalam keadaan lemah yang bertambah-tambah, dan menyapihnya dalam dua tahun. Bersyukurlah kepada-Ku dan kepada dua orang ibu bapakmu, hanya kepada-Kulah kembalimu

Dalam ayat tersebut Allah menjelaskan bahwa maksud dari "berbuat baik" adalah agar manusia selalu bersyukur menerima nikmat yang telah dilimpahkan kepada mereka, dan bersyukur pula kepada ibu bapak karena keduanya yang membesarkan, memelihara, mendidik serta bertanggung jawab atas diri mereka, sejak dalam kandungan sampai mereka dewasa. Masa membesarkan anak merupakan masa sulit karena ibu bapak menanggung segala macam kesusahan dan penderitaan, baik dalam menjaga maupun dalam usaha mencari nafkah bagi anaknya.

\section{LANGKAH-LANGKANG UNTUK MENGEMBANGKAN MORAL KEAGAMAAN ANAK}

Pada jenjang Taman Kanak-kanak, anak lebih diperkenalkan pada realitas hidup bersama yang mempunyai aturan dan nilai hidup. Proses ini dilaksanakan melalui berbagai bentuk kegiatan yang membuat anak senang dan merasakan kebaikan dan tatanan serta nilai hidup tersebut. Langkah-langkah untuk mengembangkan hal tersebut diantara- nya (Zuriah, 2007:41-44):

\section{1) Religiusitas (Religiousity)}

Religiusitas pada anak usia dini dapat dikenalkan dengan cara membiasakan diri bersyukur dan berterima kasih kepada Allah SWT yang akan membawa suasana hidup yang menyenangkan. Untuk melatih hal ini sehingga menjadi suatu kebiasaan yang dapat dilakukan secara dini pada masa pendidikan hendaknya dengan membiasakan berperilaku baik seperti dalam berdoa sebelum atau sudah melakukan sesuatu. Seperti berdoa sebelum dan sesudah tidur, berdoa sebelum dan sesudah belajar, sebelum dan sesudah makan, dan lain sebagainya.

Selain berdoa, nilai religiusitas juga dapat ditanamkan melalui kegiatan bernyanyi yang sederhana. Kegiatan menyanyi akan memperkenalkan dan mengajarkan kepada anak untuk bersyukur dan berterima kasih. Lagu kanak-kanak yang bernuansa Islami juga akan membawa anak untuk selalu mengembangkan keagamaan mereka melalui penghayatan dari lagu tersebut.

\section{2) Sosialitas}

Anak yang terbiasa hidup dalam lingkup keluarga yang penuh dengan pendampingan, pengawasan dan fasilitasnya cukup berada, bahkan mungkin berlebih akan menjadikan anak cenderung bersifat egosentris. Situasi dalam kehidupan bermasyarakat jauh berbeda dengan situasi di dalam keluarga. Sikap hidup mau berbagi, saling memperhatikan, saling menyadari dan saling melengkapi satu sama lain perlu ditanamkan mulai dari sejak kecil. Pujian perlu diberikan kepada anak-anak yang mau berbagi, mau memperhatikan dan saling memberi dan menerima dari teman-temannya bermain, bahwa apa yang dilakukan adalah baik dan perlu 
dilakukan secara terus-menerus dalam kehidupan sehari-hari. Sebaliknya, sikap egois dan mau menang sendiri harus ditinggalkan dan dijauhi agar dapat bermasyarakat dengan teman-temannya dengan rasa tertib dan aman.

Melihat yang demikian itu, sikap sosialitas pada anak dapat diajarkan dengan cara dari pihak sekolah menyediakan alat permainan yang jumlahnya terbatas untuk anak-anak, selanjutnya pendidik mengajak anak untuk mulai memperhatikan sesamanya, mau berbagi dan menyadari bahwa dalam kehidupan bersama dalam masyarakat perlu ada aturan, saling memperhatikan dan saling mendukung. Anak diajak bersikap terbuka, rendah hati, saling menerima dan mau berbagi, serta tidak egois. Langkah awal yang bisa dilakukan berupa sikap dan perilaku mau berbagai mainan dengan teman, mau bergantian dengan teman, serta tidak asyik dengan kepentingan dan kemauan dirinya sendiri.

\section{3) Gender}

Pengenalan gender pada anak perlu ditanamkan sejak dini, misalnya dengan cara disosialisasikan kepada anak melalui permainan dan kegiatan bersama yang tidak membedakan antara laki-laki dan perempuan. Pembedaan yang ada bukanlah menunjukkan perbedaan yang esensial, tetapi pembedaan yang berdasarkan kebiasaan belaka. Secara esensial perempuan sebenarnya bukanlah makhluk yang lemah dan perlu dikasihani, melainkan sebaliknya ia adalah makhluk yang kuat dan memiliki potensi yang bisa dioptimalkan eksistensinya. Mindset dan pandangan yang demikian harus ditanamkan pada diri anak-anak di sekolah. Begitu juga anak laki-laki, bukanlah identik dengan kasar dan hanya mengandalkan otot. Hal ini pun harus disosialisasikan sejak dini di lingkungan sekolah melalui permainan dan kegiatan bersama yang tidak membedakan antara laki-laki dengan perempuan

\section{4) Keadilan}

Nilai keadilan dapat ditanamkan dalam pendidikan di tingkat Kanak-kanak dengan cara memberi kesempatan yang sama untuk semua anak baik laki-laki maupun perempuan untuk mengerjakan tugas yang diberikan oleh pendidik baik melalui kegiatan menyanyi, permainan maupun tugas-tugas lainnya. Apabila ada anak yang mendominasi, dapat diberi pemahaman dan pengertian sederhana untuk bergantian dengan yang lain. Dalam hal ini pendidik dituntut agar bersungguh-sungguh memperhatikan peserta didik satu persatu. Pendidik harus lebih dekat dengan anak dan selalu memperhatikan siapa yang sudah mendapat kesempatan dan siapa yang belum, siapa yang menonjol dan siapa yang membutuhkan perhatian dan dorongan untuk maju dan lebih berani tampil.

\section{5) Demokrasi}

Nilai demokrasi dapat ditanamkan dan diajarkan sejak dini melalui kegiatan menghargai perbedaan yang tahap demi tahap harus diarahkan pada pertanggungjawaban yang benar dan sesuai dengan nalar anak. Untuk memulainya di lingkungan sekolah Taman Kanak-kanak dapat dilakukan melalui kegiatan menggambar. Anak diberi kebebasan untuk menggambar yang sesuai dengan imajinasi dan kreatifitasnya masing-masing. Apapun hasilnya, anak tetap diberi apresiasi. Apresiasi yang diberikan merupakan bagian dari penghargaan akan perbedaan (Zuriah, 2007:43).

\section{6) Kejujuran}

Kejujuran merupakan salah satu bentuk kecerdasan moral. Anak yang memili- 
ki sifat jujur dianggap memiliki kecerdasan moral cukup baik. Menanamkan kecerdasan moral seperti kejujuran kepada anak jauh lebih sulit dibanding melatih kecerdasan intelegensinya (Anwar dan Arsyad, 2009:49-50). Akan tetapi penanaman nilai kejujuran dapat dilakukan melalui kegiatan keseharian yang sederhana dan sebagai suatu kebiasaan, yaitu perilaku yang dapat membedakan milik pribadi dan milik orang lain. Kemampuan dasar untuk membedakan merupakan dasar untuk bersikap jujur. Oleh karena itu, dapat dikombinasikan dengan kebiasaan dan sopan santun dalam hal pinjam-meminjam. Apabila mau menggunakan barang hak milik orang lain, selalu meminta izin dan setelah selesai harus mengembalikannya dan selalu mengucapkan terima kasih.

Begitu juga apabila menemukan barang milik orang lain selalu mengumumkan atau menyerahkannya kepada pendidik untuk diumumkan pada teman-teman pada kesempatan lain. Kemudian sebagai kompensasi dan bentuk perhatian pendidik atas perilaku dan sikap baik dan benar dari peserta didik tadi, pendidik memberikan pujian secara terbuka di hadapan teman-temannya bahwa, sikap dan tindakan yang dilakukan temannya adalah benar dan perlu ditiru juga oleh teman-temannya. Hal seperti ini akan berdampak baik pada sikap dan perilakunya di masyarakat kelak.

\section{7) Kemandirian}

Pada awal pertama kali masuk sekolah Taman Kanak-kanak, anak-anak biasanya tidak mau ditinggalkan oleh orang tua atau pengasuhnya. Hal seperti inilah yang sering menghambat kemandirian anak (Supardi dan Aqila, 2010:49). Akan tetapi hal tersebut dapat diatasi melalui kegiatan bersama, anak diajak untuk terbiasa dan senang bermain dengan teman sebayanya. Dengan perasaan senang bermain bersama teman sebayanya, setahap demi setahap anak mulai siap untuk sekolah tanpa harus ditunggui. Pada tahap selanjutnya yang perlu dilakukan oleh pendidik adalah membiasakan anak untuk membereskan dan mengembalikan permainan ke tempat yang sudah ditentukan. Kemandirian yang sederhana ini juga membawa anak pada sikap memiliki atas barang-barang yang dipakainya, serta tidak membiarkan tergeletak dan berantakan. Anak dibiasakan hidup tertib dan teratur serta bertanggungjawab terhadap kegiatan yang telah dilakukan.

\section{8) Daya Juang}

Penanaman nilai daya juang di lingkungan Taman Kanak-kanak terlihat pada kegiatan secara berkala, anak diajak jalan-jalan yang wajar, tidak terlalu jauh dan tidak terlalu dekat. Kemampuan menempuh jarak tertentu menjadi dasar untuk mengembangkan daya juangnya. Melalui kegiatan ini anak juga di ajak mengenal alam sekitar dan cara hidup bersama di jalan umum seperti disiplin, tertib, hati-hati untuk keselamatan diri dan bersama, menghargai kebersihan dengan tidak membuang sampah sembarangan. Disamping itu anak juga diajak mencintai dan mengakui kebesaran Allah SWT yang menciptakan keindahan alam semesta ini, serta berusaha mensyukuri nikmat yang diberikan dengan cara menjaganya.

\section{9) Tanggung Jawab}

Nilai tanggungjawab di sekolah Taman Kanak-kanak harus ditanamkan kepada anak tepatnya ketika ia di dalam kelas. Hal ini dapat dilakukan melalui kegiatan permainan atau tugas-tugas yang menggunakan alat (Santi, 2009:29). Tanggungjawab ini seperti halnya menjaga agar alat permainan tidak 
mudah rusak, berani melaporkan apabila alat permainan rusak merupakan awal pembentukan sikap dan perilaku bertanggungjawab. Melalui kegiatan dan kebiasaan seperti itu, anak-anak diajarkan untuk tahu bagaimana menjaga dan memelihara permainan dan peralatan yang digunakannya.

\section{0) Penghargaan Terhadap Sekitar}

Penghargaan terhadap alam dapat ditumbuhkan dengan cara mengajak dan mengajari anak memelihara tanaman di sekolah. Anak diajak berkebun dan diberi tanggungjawab memelihara satu tanaman, serta tidak membuang sampah sembarangan. Menjaga dan memelihara tanaman merupakan awal untuk mencintai lingkungan alam yang lebih luas lagi di jagat semesta ini (Zuriah, 2007:41-45).

Pembentukan sikap, pembinaan moral dan pribadi pada umumnya terjadi melalui pengalaman sejak kecil. Pendidik atau pembimbing utama dan pertama adalah orang tua kemudian guru. Semua pengalaman yang dilalui anak pada masa kecil merupakan unsur terpenting dalam hidupnya. Sikap anak terhadap agama didapat melalui pengalaman yang didapat dari orang tua serta keluarga, kemudian diperbaiki dan dikembangkan di sekolah. Adapun latihan keagamaan yang menyangkut akhlak dan ibadah sosial yang sesuai dengan ajaran agama jauh lebih penting dibandingkan dengan penjelasan dengan kata-kata yang bersifat teoritis. Latihan disini dilakukan melalui contoh yang diberikan oleh guru atau orang tua. Oleh karena itu, pendidik agama hendaknya mempunyai kepribadian yang dapat mencerminkan ajaran agama yang akan diajarkan kepada anak didiknya, dan sikapnya dalam melatih kebiasaan-kebiasaan yang baik yang sesuai dengan ajaran agama dan hendaknya diberikan dengan cara yang menyenangkan dan tidak kaku (Zakiah Darajat, 2005:55-56).

Demikian halnya pada pengembangan moral keagamaan pada anak, juga harus dilakukan dengan latihan-latihan langsung dan dibiasakan untuk melakukan terus-menerus sehingga nilai-nilai moral keagamaan tidak hanya sebatas pengetahuan tentang apa dan bagaimana moral agama itu sendiri, tetapi bagaimana nilai-nilai moral keagamaan yang ada itu diterapkan dan dipraktekkan dalam kehidupan sehari-hari.

\section{METODE PENGEMBANGAN MORAL KEAGAMAAN ANAK}

Pendidikan anak usia dini bertujuan membimbing dan mengembangkan potensi setiap anak agar dapat berkembang secara optimal sesuai tipe kecerdasannya. Oleh karena itu pendidik atau guru harus memahami kebutuhan khusus atau kebutuhan individual anak. Akan tetapi, perlu disadari pula bahwa ada faktor-faktor yang sulit atau tidak dapat dirubah dalam diri anak yaitu faktor genetis. Karena itulah pendidikan anak usia dini diarahkan untuk memfasilitasi setiap anak dengan lingkungan dan bimbingan belajar yang tepat agar anak dapat berkembang sesuai kapasitas genetisnya. Anak usia dini dipandang sebagai individu yang baru mulai mengenal dunia. Ia belum mengetahui tata krama, sopan santun, aturan, norma, etika, dan berbagai hal lain yang terkait dengan kehidupan duniawi. Usia dini merupakan masa bagi seorang anak untuk belajar berkomunikasi dengan orang lain serta memahaminya. Oleh karena itu, seorang anak perlu dibimbing agar mampu memahami berbagai hal tentang kehidupan dunia dan segala isinya.

Dalam membimbing dan mengembangkan potensi anak usia dini perlu memilih 
metode yang tepat. Pemilihan metode yang dilakukan pendidik atau guru semestinya dilandasi alasan yang kuat dan faktor-faktor pendukungnya seperti karakteristik tujuan kegiatan dan karakteristik anak yang diajar. Karakteristik tujuan adalah pengembangan kognitif, pengembangan kreativitas, pengembangan bahasa, pengembangan emosi, pengembangan motorik, dan pengembangan nilai serta pengembangan sikap dan perilaku. Untuk mengembangkan nilai dan sikap anak dapat dipergunakan metode-metode yang memungkinkan terbentuknya kebiasaan-kebiasaan yang didasari oleh nilai-nilai agama dan moralitas agar anak dapat menjalani kehidupan sesuai dengan norma yang berlaku di masyarakat.

Setiap guru akan menggunakan metode sesuai dengan gaya melaksanakan kegiatan. Tetapi yang harus diingat bahwa Taman Kanak-kanak memiliki cara yang khas. Oleh karena itu, ada metode-metode yang lebih sesuai bagi anak Taman Kanak-kanak dibandingkan dengan metode-metode lain. Misalnya saja guru TK jarang sekali yang menggunakan metode ceramah. Orang akan segera menyadari bahwa metode ceramah tidak sesuai dan tidak banyak berarti apabila diterapkan untuk anak TK. Metode-metode yang memungkinkan anak dapat melakukan hubungan atau sosialisasi dengan yang lain akan lebih sesuai dengan kebutuhan dan minat anak. Melalui kedekatan hubungan guru dan anak, seorang guru akan dapat mengembangkan kekuatan pendidik yang sangat penting (Moeslichatun, 2004: 7).

Dalam pelaksanaan penanaman nilai moral pada anak usia dini banyak metode yang dapat digunakan oleh guru atau pendidik. Namun sebelum memilih dan menerapkan metode yang ada perlu diketahui bahwa guru atau pendidik harus memahami metode yang akan dipakai, karena ini akan berpengaruh terhadap optimal tidaknya keberhasilan penanaman nilai moral tersebut. Metode dalam penanaman nilai moral kepada anak usia dini sangatlah bervariasi, diantaranya bercerita, bernyanyi, bermain, bersajak dan karya wisata. Masing-masing metode mempunyai kelemahan dan kelebihan. Penggunaan salah satu metode penanaman nilai moral yang dipilih tentunya disesuaikan dengan kondisi sekolah atau kemampuan seorang guru dalam menerapkannya.

Metode pendidikan yang relevan dengan usia anak tingkat pra sekolah ini pada umumnya berdasarkan pendekatan yang bersifat deficit (menyebar) dari pengalaman sekitar yang sempit kepada pengenalan lingkungan alam yang lebih luas (Arifin, 1995:212).

Ulwan (1981:2) menjelaskan bahwa, adapun beberapa metode yang dapat dijadikan dalam pengembangan moral keagamaan anak, diantaranya yaitu:

\section{1) Pendidikan dengan keteladanan}

Keteladanan menjadi hal yang sangat dominan dalam mendidik anak. Anak pada dasarnya akan meniru apa yang dilakukan orang-orang di sekelilingnnya (Supardi dan Aqila, 2010:36). Pendidikan keteladanan ini merupakan salah satu teknik pendidikan yang efektif, apalagi bila ditanamkan pada masa kanak-kanak karena pada masa kanak-kanak segala ilmu yang diperolehnya akan mudah diterima oleh anak tersebut dengan melihat dari pendidiknya. Maka seorang pendidik harus selalu memberi contoh yang baik bagi muridnya. Sebagaimana firman Allah dalam surat Al-Ahzab ayat 21 yang mengutus Nabi Muhammad SAW untuk menjadi teladan buat manusia: 


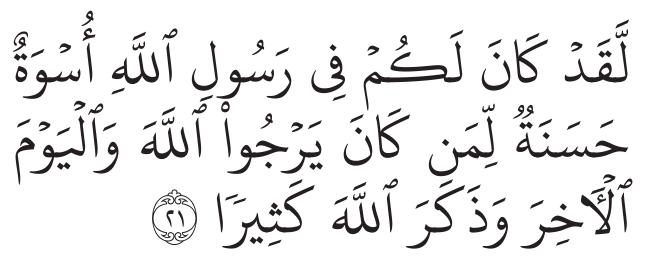

Sesungguhnya telah ada pada (diri) Rasulullah itu suri teladan yang baik.

Oleh karena itu, Rasulullah SAW merupakan teladan terbesar buat umat manusia. Di dalam sejarah manusia yang panjang beliau adalah seorang pendidik, seorang yang memberi petunjuk kepada manusia dengan tingkahlakunya sendiri, kepribadian Rasulullah sesungguhnya bukanlah hanya teladan buat suatu masa, satu generasi, satu bangsa, satu golongan atau satu lingkungan tertentu. Beliau merupakan teladan universal, buat seluruh manusia dan seluruh generasi yang ada di bumi sampai hari akhir.

\section{2) Pendidikan dengan Pembiasaan}

Sebagai permulaan dan sebagai pangkal pendidikan, pembiasaan merupakan alat satu-satunya. Sejak lahir anak-anak harus dilatih dengan kebiasaan-kebiasaan dan perbuatan-perbuatan yang baik, seperti dimandikan dan ditidurkan pada waktu tertentu, diberi makan dengan teratur dan sebagainya. Semakin besar anak itu, maka semakin besar pula kebiasaan-kebiasaan yang baik itu harus tetap diberikan dan dilaksanakan. Anakanak dapat menurut dan taat kepada peraturan-peraturan dengan membiasakannya dengan perbuatan-perbuatan yang baik, baik di dalam rumah tangga atau keluarga, di sekolah dan juga tempat lain. Hal ini sebagaimana dalam kamus oxford yang menjelaskan bahwa:
Habit is a thing that you do often and almost without thinking, especially sometime that is hard to stop doing (As Homby, 2000:576).

(Sesuatu yang sering anda lakukan dan hampir tanpa berfikir, terutama sesuatu yang sulit berhenti untuk melakukan).

Sedangkan menurut Abdullah Nashih Ulwan dalam karangannya yang berjudul Tarbiyatul Aulad fil Islam (Pedoman Pendidikan Anak dalam Islam) menjelaskan bahwa: Metode pendidikan pada anak terutama dalam memperbaiki anak yang paling berperan penting adalah dengan metode pengajaran dan pembiasaan.

Adapun yang dimaksud dengan pengajaran adalah upaya teoritis dalam perbaikan dan pendidikan.

Sedangkan pembiasaan adalah upaya praktis dan pembentukan (pembinaan) dan persiapan.

Karenanya, setelah diketahui bahwa kecenderungan dan naluri anak-anak dalam pengajaran dan pembiasaan adalah sangat besar dibanding usia lainnya, maka hendaklah para pendidik, ayah dan ibu, hendaknya memusatkan perhatian pada pengajaran tentang kebaikan dan upaya membiasakannya sejak ia mulai memahami realita kehidupan ini ('Ulwan, 1997:507).

Metode pembiasaan sendiri merupakan suatu kegiatan untuk melakukan hal yang sama, berulang-ulang secara sungguh-sungguh dengan tujuan untuk memperkuat suatu asosiasi atau menyempurnakan suatu ketrampilan agar menjadi terbiasa. Dengan kata lain metode pembiasaan merupakan cara mendidik anak dengan penanaman proses kebiasaan (Noer Aly, 1997:184). Hal tersebut dimaksudkan agar anak mampu untuk mem- 
biasakan diri pada perbuatan-perbuatan yang baik oleh norma, agama maupun hukum yang berlaku.

Ada hal-hal penting yang harus diketahui oleh para pendidik dalam hal mengajarkan kebaikan kepada anak-anak dan membiasakan mereka berbudi luhur, yaitu dengan cara mengikuti metode pemberian dorongan dengan kata-kata baik, dan memberikan hadiah. Terkadang memakai metode pengenalan untuk disenangi dan dengan metode pengenalan untuk dibenci. Semua metode ini bermanfaat dalam upaya membiasakan anak dengan keutamaan-keutamaan jiwa, akhlak dan etika sosial ('Ulwan, 1997:63).

Hendaknya setiap pendidik menyadari bahwa dalam pembinaan pribadi anak sangat diperlukan pembiasaan-pembiasaan dan latihan-latihan yang cocok dan sesuai dengan perkembangan jiwanya, karena pembiasaan dan latihan tersebut akan membentuk sikap tertentu pada anak. Lambat laun sikap itu akan bertambah jelas dan kuat, akhirnya tidak tergoyahkan lagi, karena telah masuk menjadi bagian dari pribadinya (Zakiah Darajat, 2005:61-62).

Pembiasaan-pembiasaan tersebut diantaranya adalah akhlaqul karimah, seperti (a) mengucapkan salam; (b) membaca basmalah pada saat akan mengerjakan sesuatu; (c) membaca hamdalah pada saat mendapatkan kenikmatan dan setelah mengerjakan sesuatu; (d) menghormati orang lain; (e) memberi shodaqoh; (f) memelihara kebersihan. Adapun doa-doa yang diajarkan: (a) doa sebelum makan dan sesudahnya; (b) doa keluar dan masuk rumah; (c) doa mau tidur dan bangun tidur; (d) doa untuk orang tua; (e) doa keselamatan di dunia dan akhirat.

3) Pendidikan dengan Nasehat

Alquran telah memberikan pelajaran kepada kita bagaimana metode nasehat sangat efektif dalam suatu kehidupan. Apabila dicermati keadaan psikologis anak, pendidikan dengan nasehat memberi nilai yang sangat positif pada masa kanak-kanak. Seorang pendidik atau pengajar yang baik akan selalu menggunakan cara yang terbaik dalam memberikan nasehat kepada anak didiknya agar mereka senang dan rela menerima nasehatnya (Untung, 2007:169).

Anak akan tahu sesuatu itu baik atau jelek apabila ada arahan dan nasehat dari orang dewasa (atau pendidik). Tanpa nasehat dan arahan anak-anak hanya mengerti dorongan nafsu dan emosinya. Nasehat-nasehat itu diberikan kepada anak agar mendapatkan pengertian tentang perbuatan dan perilakunya sehari-hari, sehingga setelah ia dewasa menjadi teguh dan kuat dalam pribadinya (Zainuddin, 1991:81).

Karena hal itu pula Alquran banyak mencontohkan ayat yang berupa nasehat seperti ucapan Nabi Ibrahim AS. dalam surat Al-Baqarah ayat 132:

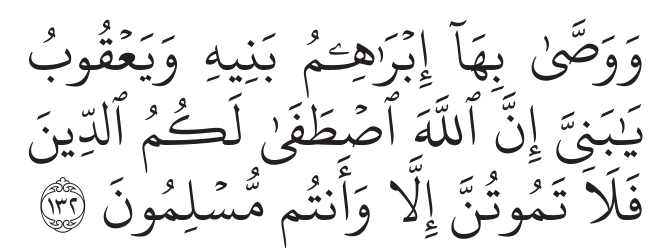

Hai anak-anakku! Sesungguhnya Allah telah memilih agama ini bagimu, maka janganlah kamu mati kecuali dalam memeluk agama Islam.

\section{4) Pendidikan dengan Kisah atau Cerita}

Bercerita merupakan cara untuk meneruskan warisan budaya dari satu generasi ke generasi berikutnya. Bercerita juga mempunyai makna penting bagi perkembangan anak TK karena melalui bercerita kita dapat:

a) Mengkomunikasikan nilai-nilai budaya.

b) Mengkomunikasikan nilai-nilai sosial. 
c) Mengkomunikasikan nilai-nilai keagamaan.

d) Menanamkan etos kerja dan etos waktu.

e) Membantu mengembangkan fantasi anak.

f) Membantu mengembangkan dimensi bahasa anak (Moeslichatoen, 2004:26-27).

Di dalam Alquran juga diceritakan, bagaimana Alquran mendidik umat manusia melalui kisah-kisah para Nabi dan Rasul. Kisah-kisah Alquran tersaji dalam bentuk yang sempurna, tuntutan, peringatan, janji yang semuanya tersaji dalam bentuk berita yang beralur fikir logis. Tokoh-tokoh yang disajikan biasanya sesuai dengan pencapaian tujuan edukatif. Kisah-kisah Alquran berisi tentang tabiat manusia yang ditampilkan secara kontras dalam wujud tokoh-tokoh cerita di dalamnya. Para Rasul dan kaum mukmin mewakili keagungan dan kemuliaan sedang kaum musyrikin mewakili kejahatan. Dalam setiap alur cerita terlihat bagaimana perjuangan para Rasul melawan kebatilan dengan penuh kesabaran dan diakhiri dengan rahmat Allah bagi orang-orang yang beriman dan hukuman bagi orang musyrikin.

Dengan alur pikir yang demikian, kisah Qur'ani akan sangat membantu pendidik dalam menanamkan akhlak pada masa kanak-kanak, misalnya kisah Yusuf yang diawali dengan mimpi Yusuf a.s disertai dengan janji Allah dan nikmat bagi keluarga yang miskin tetapi tetap mengajak ke jalan Allah. Selanjutnya berbagai musibah dan kesusahan yang bertubi-tubi menimpa tokoh Yusuf a.s karena berjuang di jalan Allah. Begitu juga dengan tokoh saudara-saudaranya yang dihadirkan sebagai tokoh yang penuh dengan kecemburuan, hasud, dengki, bersekongkol untuk mengikuti hawa nafsunya. Kemudian tampil pula tokoh Ya'kub sebagai figur orang tua yang mencintai putranya. Dari tokoh-tokoh cerita diharapkan akan menggugah perasaan anak untuk ikut berbaur dalam alur cerita yang pada akhirnya akan muncul perasaan simpati untuk meniru tokoh idola. Hal ini sangat sejalan dengan proses imitasi anak. Selanjutnya dengan alur cerita yang kontradiktif diharapkan dalam diri anak muncul keyakinan bahwa yang benar selalu mengalahkan yang batil.

\section{5) Pendidikan dengan Hukuman}

Metode hukuman ini perlu sekiranya diterapkan oleh pendidik maupun orang tua agar anak jera untuk berperilaku yang buruk dan tidak mengulangi kesalahan. Di bawah ini metode yang dipakai Islam dalam memberikan hukuman pada anak:

a) Lemah lembut dan kasih sayang adalah dasar muamalah dengan anak.

b) Menjaga tabiat anak yang salah dalam menggunakan hukuman.

c) Dalam upaya memperbaiki, hendaknya dilakukan secara bertahap dari yang paling ringan hingga yang paling keras ('Ulwan, 1997:155-158).

Seorang pendidik yang sukses tidak dibenarkan memberikan sanksi fisik kepada anak kecuali sedikit saja. Itupun baru boleh dilakukan jika memang benar-benar diperlukan. Pendidik juga diharapkan untuk selalu mendahulukan memberi hadiah daripada sanksi. Hal ini penting untuk memberi motivasi kepada anak dalam pelajaran dan pendidikan (Jamil Zainu, 2002:141).

Hal terpenting yang harus diperhatikan dalam menggunakan metode hukuman pada anak-anak ialah bahwa mereka mempunyai keadaan psikologis yang berlainan. Ada yang berpembawaan tenang, keras, emosional, sentimental dan sebagainya tergantung pada keturunan, faktor lingkungan dan faktor-faktor lain yang berpengaruh. Oleh karena itu pendidik harus sangat hati-hati dalam memberikan hukuman pada masing-mas- 
ing anak. Kadang ada yang dengan isyarat anak sudah mengerti akan tetapi kadangkala ada yang harus dengan kekerasan. Misalnya memberi hukuman dengan cara memukul, akan tetapi Islam memberi batasan dan persyaratan, sehingga pukulan tidak keluar dari maksud pendidikan yaitu untuk memperbaiki dan menjerakan bukan menjadi sebuah pembalasan.

Dalam penjelasan lain, Otib Satibi Hidayat (2005) menjelaskan secara terperinci metode-metode dalam pengembangan aspek moral dan agama pada anak sebagai berikut: Pertama, metode bercerita. Bercerita dapat dijadikan metode untuk menyampaikan nilai-nilai yang berlaku dalam masyarakat. Dalam cerita atau dongeng dapat ditanamkan berbagai macam nilai moral, nilai agama, nilai sosial, nilai budaya, dan sebagainya. Ketika bercerita seorang guru juga dapat menggunakan alat peraga untuk mengatasi keterbatasan anak yang belum mampu berpikir secara abstrak. Alat peraga yang dapat digunakan antara lain, boneka, tanaman, benda-benda tiruan, dan lain-lain. Selain itu guru juga bisa memanfaatkan kemampuan olah vokal yang dimiliknya untuk membuat cerita itu lebih hidup, sehingga lebih menarik perhatian siswa.

Kedua, metode bernyanyi. Metode bernyanyi adalah suatu pendekatan pembelajaran secara nyata yang mampu membuat anak senang dan bergembira. Anak diarahkan pada situasi dan kondisi psikis untuk membangun jiwa yang bahagia, senang menikmati keindahan, mengembangkan rasa melalui ungkapan kata dan nada. Pesan-pesan pendidikan berupa nilai dan moral yang dikenalkan kepada anak tentunya tidak mudah untuk diterima dan dipahami secara baik. Anak tidak dapat disamakan dengan orang dewasa. Anak merupakan pribadi yang memiliki keunikan tersendiri. Pola pikir dan kedewasaan seorang anak dalam menentukan sikap dan perilakunya juga masih jauh dibandingkan dengan orang dewasa. Anak tidak cocok hanya dikenalkan tentang nilai dan moral melalui ceramah atau tanya jawab saja.

Ketiga, metode bersajak atau syair. Pendekatan pembelajaran melalui kegiatan membaca sajak merupakan salah satu kegiatan yang akan menimbulkan rasa senang, gembira, dan bahagia pada diri anak. Secara psikologis anak Taman Kanak-kanak sangat haus dengan dorongan rasa ingin tahu, ingin mencoba segala sesuatu, dan ingin melakukan sesuatu yang belum pernah dialami atau dilakukannya. Melalui metode sajak guru bisa menanamkan nilai-nilai moral kepada anak. Sajak merupakan metode yang juga dapat membuat anak merasa senang, gembira dan bahagia. Melalui sajak anak dapat dibawa ke dalam suasana indah, halus, dan menghargai arti sebuah seni. Disamping itu anak juga bisa dibawa untuk menghargai makna dari untaian kalimat yang ada dalam sajak itu. Secara nilai moral, melalui sajak anak akan memiliki kemampuan untuk menghargai perasaan, karya serta keberanian untuk mengungkap sesuatu melalui sajak sederhana.

Keempat, metode karyawisata. Metode karya wisata bertujuan untuk mengembangkan aspek perkembangan anak Taman Kanak-kanak yang sesuai dengan kebutuhannya. Misalnya pengembangan aspek kognitif, bahasa, kreativitas, emosi, kehidupan bermasyarakat, dan penghargaan pada karya atau jasa orang lain. Tujuan berkarya wisata ini perlu dihubungkan dengan tema-tema yang sesuai dengan pengembangan aspek perkembangan anak Taman Kanakkanak. Tema yang sesuai seperti: binatang, pekerjaan, kehidupan kota atau desa, pesisir, dan pegunungan. 
Kelima, pembiasaan dalam berperilaku. Kurikulum yang berlaku di TK terkait dengan penanaman moral, lebih banyak dilakukan melalui pembiasaan-pembiasaan tingkah laku dalam proses pembelajaran. Ini dapat dilihat misalnya, pada berdoa sebelum dan sesudah belajar, berdoa sebelum makan dan minum, mengucap salam kepada guru dan teman, merapikan mainan setelah belajar, berbaris sebelum masuk kelas dan sebagainya. Pembiasaan ini hendaknya dilakukan secara konsisten. Jika anak melanggar segera diberi peringatan.

Keenam, metode bermain. Dalam bermain ternyata banyak sekali terkandung nilai moral, diantaranya mau mengalah, kerjasama, tolong menolong, budaya antri dan menghormati teman. Nilai moral mau mengalah terjadi manakala siswa mau mengalah terhadap teman lainnya yang lebih membutuhkan untuk satu jenis mainan. Pengertian dan pemahaman terhadap nilai moral mau menerima kekalahan atau mengalah adalah salah satu hal yang harus ditanamkan sejak dini. Seringkali terjadi sikap moral tidak terpuji seperti perusakan dan tindakan anarkis lainnya yang dilakukan oleh oknum tertentu ketika ia kalah dalam suatu persaingan, misalnya dalam pemilihan kepala desa, bupati, gubernur, atau bahkan dalam pemilihan presiden. Oleh karena itu betapa penting untuk menanamkan nilai moral untuk mau menerima kekalahan sejak usia dini.

Ketujuh, metode outbond. Metode Outbond merupakan suatu kegiatan yang memungkinkan anak untuk bersatu dengan alam. Melalui kegiatan outbond siswa akan dengan leluasa menikmati segala bentuk tanaman, hewan, dan mahluk ciptaan Allah yang lain. Cara ini dilakukan agar anak tidak hanya memahami apa yang diceritakan atau dituturkan oleh guru atau pendidik di dalam kelas. Me- lainkan mereka diajak langsung melihat atau memperhatikan sesuatu yang sebelumnya pernah diceritakan di dalam kelas, sehingga apa yang terjadi di kelas akan ada sinkronisasi dengan apa yang tampak di lapangan atau alam terbuka.

Kedelapan, bermain peran. Bermain peran merupakan salah satu metode yang digunakan dalam menanamkan nilai moral kepada anak TK. Dengan bermain peran anak akan mempunyai kesadaran merasakan jika ia menjadi seseorang yang dia perankan dalam kegiatan bermain peran. Misalnya tema bermain peran tentang kasih sayang dalam keluarga. Anak akan merasakan bagaimana seorang ayah harus menyayangi anggota keluarga, bagaimana seorang ibu harus menyayangi keluarga, begitu juga bagaimana dengan anak-anaknya.

Kesembilan, metode diskusi. Diskusi yang dimaksud di sini adalah mendiskusikan tentang suatu peristiwa. Biasanya dilakukan dengan cara siswa diminta untuk memperhatikan sebuah tayangan dari CD, kemudian setelah selesai siswa diajak berdiskusi tentang isi tayangan tersebut. Isi diskusinya antara lain mengapa hal tersebut dilakukan, mengapa anak itu dikatakan baik, mengapa harus menyayangi dan sebagainya.

Kesepuluh, metode teladan. Menurut Cheppy Hari Cahyono (1995:364-370) guru moral yang ideal adalah mereka yang dapat menempatkan dirinya sebagai fasilitator, pemimpin, orang tua dan bahkan tempat menyandarkan kepercayaan, serta membantu orang lain dalam melakukan refleksi. Guru hendaknya menjadi figur yang dapat dicontoh dalam bertingkah laku oleh siswanya. Secara kodrati manusia merupakan makhluk peniru atau suka melakukan hal yang sama terhadap sesuatu yang dilihat. Apalagi anak-anak, ia akan senantiasa dan sangat mudah meniru 
sesuatu yang baru dan belum pernah dikenalnya, baik itu perilaku maupun ucapan orang lain.

Demikianlah berbagai metode pendidikan yang memberikan kesan pada anak. Metode-metode tersebut merupakan metode yang esensial, praktikal dan efektif jika dapat dilaksanakan dengan segala batasan dan persyaratan, dan tidak diragukan lagi anak akan menjadi manusia yang berarti, dihormati, dikenal di antara kaumnya sebagai orang yang bertaqwa, ahli beribadah dan ihsan.

Di lembaga pendidikan anak usia dini khususnya di Taman Kanak-Kanak, moral dan nilai-nilai agama ditanamkan melalui pembiasaan. Salah satu perilaku yang ditanamkan pada anak usia dini adalah berdo'a sebelum dan setelah melakukan kegiatan. Dalam kegiatan sehari-hari, guru atau pendidik TK banyak yang mengajarkankan do'a-do'a tertentu yang cukup panjang setiap hendak melakukan kegiatan tertentu di kelas, seperti do'a sebelum belajar, sebelum makan, setelah makan dan do'a-do'a lain yang masih bersifat hafalan saja dan tidak ditekankan makna atau nilai-nilai yang terkandung dalam bacaan doa tersebut. Bahkan di beberapa TK terutama TK-TK dibawah yayasan Islam pendidik yang mengajarkan do'a-do'a dengan menggunakan bahasa Arab yang tidak disertakan artinya, sehingga anak hanya hapal apa yang diucapkan tanpa tahu maksud ucapannya. Beberapa do'a tersebut secara rutin dibiasakan pada anak dengan cara anak diminta mengucapkan do'a-do'a tersebut dengan suara yang keras.

Melihat pembelajaran moral dan nilai-nilai agama melalui pembacaan do'a tersebut tampak bahwa anak belum tentu dapat menangkap makna atau nilai dari do'a yang diucapkan tersebut, karena bahasa yang dipergunakan adalah bahasa Arab yang tidak dipahami oleh anak. Di samping itu, proses pembelajaranyang diterapkan kadang kurang aplikatif karena ketika mengajarkan do'a, anak diminta mengucapkan do'a-do'a tersebut dengan suara keras di kelas.

Pengenalan do'a akan lebih bermakna apabila pendidik berusaha menghadirkan situasi nyata dalam bentuk kegiatan sehari-hari baik dirumah maupun di sekolah. Ketika anak hendak belajar pendidik mengajak anak berdo'a yang sebelumnya dijelaskan kenapa kita harus berdo'a, dan menjelaskan pula makna do'a yang diucapkannya, sehingga, do'a-do'a yang sering diajarkan guru atau pendidik akan dimengerti anak maksud dan makna dari do'a tersebut. Proses pembelajaran tersebut ditanamkan secara terus menerus melalui pembiasaan anak secara langsung ketika akan melakukan suatu kegiatan. Diharapkan bacaan do'a tersebut akan semakin "terinternalisasi” dalam diri anak.

Sesuai dengan tahap perkembangan moral Kohlberg, anak termasuk pada tahap perkembangan moral pra-konvensional, dimana tingkah laku anak dikendalikan oleh akibat fisik yang ditimbulkan dari perbuatannya yang biasanya muncul dalam bentuk hadiah dan hukuman. Dengan demikian penanaman moral dan nilai-nilai agama pada masa ini perlu ditanamkan dengan memberikan hadiah (reward) ketika anak melakukan sesuatu yang positif dan memberikan hukuman (punishment) atau hukuman tertentu yang sifatnya mendidik jika anak melakukan perilaku yang kurang sesuai.

Penjabaran kompetensi pendidikan moral dan nilai-nilai agama, sebagaimana dijabarkan oleh kurikulum pendidikan anak usia dini menunjukkan bahwa, pendidikan moral dan nilai-nilai agama ditanamkan tidak hanya dalam kegiatan ibadah yang sifatnya rutinitas tetapi juga melalui berbagai aktifitas 
sehari-hari. Mencakup bagaimana penanaman kasih sayang dengan sesama, tanggung jawab, sopan santun, kebersihan dan kerapian dan ketertiban dalam aturan. Dengan demikian banyak cara, waktu dan kegiatan yang dapat digunakan untuk menanamkan moral dan nila-nilai agama kepada anak-anak.

\section{PENUTUP}

Anak adalah generasi penerus keluarga dan bangsa yang perlu mendapat pendidikan yang baik sehingga potensipotensi dirinya dapat berkembang dengan pesat, sehingga tumbuh menjadi manusia yang memiliki kepribadian yang tangguh dan cakap serta terampil. Oleh karena itu penting bagi keluarga dan lembaga-lembaga pendidikan berperan dan bertanggung jawab dalam memberikan berbagai macam stimulasi dan bimbingan yang tepat sehingga akan tercipta generasi penerus yang tangguh.

Usia dini atau usia 0 hingga 8 tahun merupakan the golden age, karena pada mas ini berbagai kemampuan anak tumbuh dan berkembang sangat pesat peran guru/orang tua harus memaksimalkan potensi tersebut. Pemberian stimulasi dan fasilitas yang tepat pada masa ini, akan sangat berpengaruh pada proses perkembangan anak. Sebaliknya, apabila orang tua, pendidik, dan masyarakat tidak memberikan stimulasi yang tepat bagi kemampuan anak, maka anak dapat berkembang tidak seperti yang diharapkan.

Anak tumbuh dan berkembang dengan pesat baik secara fisik, kognitif, emosi dan sosialnya. Pendidikan Anak Usia Dini mempunyai peranan penting untuk memenuhi kebutuhan perkembangan anak, termasuk kebutuhan akan moral dan nilai-nilai agama. Penanaman moral dan nilai-nilai agama sangat membantu untuk meningkatkan dan mengarahkan perkembangan anak tersebut. Penanaman moral dan nilai-nilai agama pada anak tidak sekedar kegiatan rutinitas dalam ibadah tetapi lebih tepat ditanamkan secara langsung, kongkrit dan sesuai dengan bahasa anak dalam perilaku kesehariannya. Penanaman moral dan nilai-nilai agama semenjak dini pada anak diharapkan akan menjadi bekal baginya di kemudian hari.

\section{DAFTAR PUSTAKA}

Abdur Rahman, Jamaal, Tahapan Mendidik Anak Teladan Rasulullah SAW, Bandung: Irsyad Baitus Salam, 2005.

Abdul Santhut, Khatib, Menumbuhkan Sikap Social, Moral, dan Spiritual Anak dalam Keluarga Muslim, Yogyakarta: Mitra Pustaka, 1998.

Aly, Hery Noer, Ilmu Pendidikan Islam, Jakarta: Logos Wacana Ilmu, 1999.

Aqila Smart, dan Supardi, Ide-ide Kreatif Mendidik Anak bagi Orang Tua Sibuk, Yogyakarta: Katahati, 2010 .

Arifin, Kapita Selekta Pendidikan, (Islam dan Umum), Jakarta: Bumi Aksara, 1995.

Arikunto, Suharsimi, Prosedur Penelitian Suatu Pendekatan Praktik, Jakarta: Rineka Cipta, 2006.

Arsyad Ahmad, dan Anwar, Pendidikan Anak Usia Dini; Panduan Praktis bagi Ibu dan Calon Ibu, Bandung: Alfabeta, 2009.

As hornby, Oxford Advanced Learner's Dictionary of Curent English, New York: Oxford University Press, 2000.

Azwar, Saifudin, Metodologi Penelitian, 
Yogyakarta: Pustaka Pelajar, 2005.

B. Hurlock, Elisabeth, Psikologi Perkembangan (Penerj. Istiwidayanti, dkk), Jakarta: Erlangga, 1999.

Barmawi, Bakir Yusuf, Pembinaan Kehidupan Beragama Islam Pada Anak, Semarang: Dina Utama, 1993.

Dalyono, Psikologi Pendidikan, Jakarta: Rineka Cipta, 1997.

Daradjat, Zakiah, Ilmu Pendidikan Islam, Jakarta: Bumi Aksara, 1966. , Ilmu Jiwa Agama, Jakarta: Bulan Bintang, 2005.

, Pendidikan Agama dalam Pembinaan Mental, Jakarta: Bulan Bintang, 1998.

Desmita, Psikologi Perkembangan, Bandung: Rosdakarya, 2005.

Ekawati, Wahyu Mei, Implementasi Parenting Untuk Mengembangkan Potensi Keagamaan Anak di Lembaga Taman Pendidikan Islam Anak Usia Dini (TPI AUD) Cahaya Ilmu Pedurungan Semarang, (Semarang: Perpustakaan Fakultas Tarbiyah IAIN Walisongo Semarang, 2001).

Fuaduddin, Pengasuhan Anak Dalam Keluarga Islam, Jakarta: Lembaga Kajian Agama dan Jender, 1999.

Hadi, Sutrisno, Metodologi Research Jilid 2, Yogyakarta: Andi Offset, 2004.

Hasan, Maimunah, Pendidikan Anak Usia Dini, Yogyakarta: Diva Press,
2009.

Jalaluddin, Psikologi Agama, Jakarta: PT. Raja Grafindo Persada, 1998.

Kusniati, Siti, Konsep Pendidikan Keagamaan Pada Anak Menurut Abdullah Nashih Ulwan, (Semarang: Perpustakaan Fakultas Tarbiyah IAIN Walisongo Semarang, 2006).

Mansur, Pendidikan Anak Usia Dini dalam Islam, Yogyakarta: Pustaka Pelajar, 2005.

Moeslichatoen R, Metode Pengajaran di Taman Kanak-kanak, Jakarta: Rineka Cipta, 2004.

Muhammad Al Thamy Al Syabani, Umar, Falsafah Pendidikan Islam, Terj. Drs. Hasan Langgulung, Jakarta: Bulan Bintang, 1979.

Munif, Aslahul, Impelementasi Metode Nyanyian/ lagu dalam Pembelajaran Moral Agama pada Anak Usia Pra Sekolah di RA Walisongo Jerakah Tugu Semarang, (Semarang: Perpustakaan Fakultas Tarbiyah IAIN Walisongo Semarang, 2001).

Musthafa, Asy-Syaikh Fuhaim, Manhaj Pendidikan Anak Muslim, Jakarta: Mustaqim, 2004.

Nahlawy, Abdul Rahman, Prinsip-prinsip Metode Pendidikan Islam, Penj. Dahlan dan Soelaeman, Bandung: CV. Diponegoro, 1992.

Patmonodewo, Soemiarti, Pendidikan Anak Pra Sekolah, Jakarta: Rineka Cipta, 2000. 
Quthb, Muhammad, Sang Anak dalam Naungan Pendidikan Islam, Bandung: CV. Diponegoro, 1993.

Rahmat, Jalaludin, Psikologi Agama, Jakarta: Raja Grafindo Persada, 1995.

Santi, Danar, Pendidikan Anak Usia Dini; Antara Teori dan Praktik, Jakarta: PT. Indeks, 2009.

Semiawan, Conny, Penerapan Pembelajaran pada Anak, Jakarta: PT. Indeks, 2002.

Sholihah, Iis, Penanaman Nilai-nilai Islam pada Pendidikan Pra sekolah di RA Al-Hidayah DWP IAIN Walisongo Semarang, (Semarang: Perpustakaan Fakultas Tarbiyah IAIN Walisongo Semarang, 2008).

Sjarkawi, Pembentukan Kepribadian Anak, Jakarta: PT. Bumi Aksara, 2006.

Soenarjo, Alquran dan Terjemahnya, Jakarta: tp, 1984.

Sukardi, Metodologi Penelitian Pendidikan; Kompetensi dan Praktiknya, Jakarta: Bumi Aksara, 2003

Suzuki, Shinisschi, Mengembangkan Bakat Anak Sejak Lahir, Jakarta: PT. Gramedia, 1989.

Tim Penyusun Kamus Pusat Bahasa, Kamus Besar Bahasa Indonesia, Jakarta: Balai Pustaka, 2005.

Ulwan, Abdullah Nashih, Pedoman Pendidikan Anak dalam Islam, Semarang: Asy-Syifa ${ }^{e e}, 1981$.

, Pendidikan Anak

Menurut Islam; Pemeliharaan
Kesehatan Jiwa Anak, Bandung: PT. Remaja Rosdakarya, 1990.

Tarbiyatul

Aulad fil Islam Juz II, Beirut: Darussalam li al thaba"eah wa alNasr wa al-tauzie i, 1981. , Tarbiyatul Aulad fil Islam, Beirut: Darussalam, 1997.

Untung, Moh. Slamet, Menelusuri Metode Pendidikan ala Rasulullah, Semarang: Pustaka Rizki Putra, 2007.

YusufL.N., Syamsu, Psikologi Perkembangan Anak dan Remaja, Bandung: PT. Remaja Rosdakarya, 2000.

Zainu, Muhammad bin Jamil, Solusi Pendidikan Anak Masa Kini, Jakarta: Mustaqim, 2002.

Zainuddin, Seluk Beluk Pendidikan dari AlGhazali, Jakarta: Bumi Aksara, 1991.

Zuriah, Nurul, Pendidikan Moral \& Budi Pekerti dalam Perspektif Perubahan, Jakarta: PT. Bumi Aksara, 2007.

Metodologi

Penelitian Sosial dan Pendidikan Teori-Aplikasi, Jakarta: Bumi Aksara, 2006. 